\title{
PEMBUKTIAN TINDAK PIDANA PENCUCIAN UANG TANPA DAKWAAN TINDAK PIDANA ASAL
}

\author{
Kajian Putusan Nomor 57/PID.SUS/2014/PN.SLR \\ PROVING MONEY LAUNDERING CRIME \\ WITHOUT ACCUSATION OF PREDICATE CRIME
}

\author{
An Analysis of Court Decision Number 57/PID.SUS/2014/PN.SLR
}

Halif

Fakultas Hukum Universitas Jember

Jl. Kalimantan 37 Kampus Bumi Tegalboto, Jember 68121

E-mail: halif.fh@unej.ac.id

Naskah diterima: 16 Februari 2017; revisi: 14 Agustus 2017; disetujui 14 Agustus 2017

\begin{abstract}
ABSTRAK
Dalam surat dakwaan Putusan Nomor 57/PID.SUS/2014/

PN.SLR, penuntut umum mendakwa dengan pasal tindak pidana pencucian uang tanpa bersamaan dengan pasal tindak pidana asal, sebagaimana diatur secara limitatif dalam Pasal 2 Undang-Undang Pencegahan dan Pemberantasan Tindak Pidana Pencucian Uang. Hal yang demikian berdampak kepada hakim dalam membuktikan unsur tindak pidana pencucian uang yang diketahui atau patut diduga hasil dari tindak pidana asal. Permasalahan yang menarik untuk dianalisis adalah 1) mengapa penentuan bentuk dakwaan menjadi penting dalam tindak pidana pencucian uang?; dan 2) bagaimanakah hakim membuktikan unsur tindak pidana pencucian uang jika tindak pidana asal tidak didakwakan? Untuk menganalisis permasalahan tersebut digunakanlah metode penelitian yuridis normatif dengan pendekatan perundang-undangan dan pendekatan konseptual. Penentuan bentuk dakwaan dalam tindak pidana pencucian uang menjadi dasar bagi hakim untuk menentukan sistem pembuktian dalam membuktikan unsur. Dengan pembuktian yang tepat hakim dapat membuktikan unsur tindak pidana pencucian uang. Oleh karena itu, penyusunan surat dakwaan yang tepat dalam tindak pidana pencucian uang menjadi hal yang sangat penting.
\end{abstract}

Kata kunci: pencucian uang, dakwaan, pembuktian.

\section{ABSTRACT}

In the accusation of Court Decision Number 57/PID. SUS/2014/PN.SLR, the prosecutor filed the accusation with the article of money laundering crime without referring to the article on the predicate crime, as regulated in Article 2 of Law on Money Laundering Crime. Such matters affect the judges in proving the elements of money laundering crime known or reasonably suspected to be the result of a predicate crime. Issues of interest to review in the analysis are: 1) why does determining the form of the accusation play important role in the money laundering crime? and 2) how does the judge prove the element of money laundering crime if the predicate crime is not accused? To analyse these problems, the juridical-normative method with legislative and conceptual approaches was used in this analysis. The accusation form determination in money laundering crime becomes the basis for the judge to determine the proof system in proving the element. With the precise proof the judge can prove the element of money laundering crime. It is therefore vey important to precisely write the accusation letter in the money laundering crime. However in proving the money laundering crime the predicate crime should be proved first.

Keywords: money laundering, accusation, proof. 


\section{PENDAHULUAN}

\section{A. Latar Belakang}

Tindak pidana pencucian uang merupakan proses penyembunyian atau penyamaran harta kekayaan yang dihasilkan dari tindak pidana asal, seperti tindak pidana korupsi, tindak pidana perdagangan narkoba atau tindak pidana perdagangan orang, baik melalui sistem keuangan maupun melalui sistem non- keuangan, sehingga harta kekayaan tersebut seolah-olah menjadi sah.

Sebagaimana kesimpulan yang dirumuskan Sjahdeini (2007: 5) dari beberapa pendapat tentang pengertian pencucian uang, bahwa pencucian uang adalah serangkaian kegiatan yang dilakukan oleh seseorang atau organisasi terhadap uang yang dihasilkan dari tindak pidana yang tujuannya untuk menyembunyikan atau menyamarkan asal usul dari penegak hukum dengan cara memasukkan uang tersebut ke dalam sistem keuangan (financial system) sehingga nantinya menjadi uang yang halal.

Dari pengertian tersebut nampak bahwa pencucian uang mengandung dua tindak pidana, sebagaimana rumusan pencucian uang di negaranegara ASEAN, yang merumuskan tindak pidana pencucian uang dengan tindak pidana asal (predicate offence), meskipun jenis tindak pidana asal yang dirumuskan berbeda-beda (Arief, 2013: 144-146).

Pertama, tindak pidana asal (predicate offence), tindak pidana ini merupakan tindak pidana yang menjadi sumber asal dari harta haram (dirty money) atau hasil tindak pidana (criminal proceeds) yang kemudian dicuci (Arief, 2013: 144). Jenis tindak pidana asal secara limitatif diatur dalam Pasal 2 ayat (1) Undang-Undang Nomor 8 Tahun 2010 tentang Pencegahan dan
Pemberatasan Tindak Pidana Pencucian Uang, seperti tindak pidana korupsi, tindak pidana perdagangan narkoba atau tindak pidana lain yang diancam pidana penjara empat tahun atau lebih.

Kedua,tindak pidanapencucianuang, tindak pidana ini merupakan tindakan atau perbuatan menyamarkan atau menyembunyikan harta kekayaan hasil tindak pidana asal dengan tujuan agar asal usul harta kekayaan tidak diketahui, sehingga harta kekayaan yang sebenarnya hasil dari tindak pidana (ilegal) menjadi seolah-olah harta kekayaan yang sah.

Berdasarkan uraian di atas dapat dikatakan bahwa antara tindak pidana pencucian uang dengan tindak pidana asal memiliki hubungan yang erat. Bagaimana mungkin akan terjadi tindak pidana pencucian uang jika tidak didahului oleh tindak pidana asal terlebih dahulu, sementara objek tindak pidana pencucian uang adalah harta kekayaan yang dihasilkan dari tindak pidana asal. Artinya, tindak pidana pencucian uang tidak akan terjadi jikalau tidak didahului oleh tindak pidana asal.

Hubungan tersebut ternyata menimbulkan permasalahan dalam penegakan hukum, baik pada tingkat penyidikan, penuntutan atau pada saat pembuktian di sidang pengadilan. Pada tingkat penyidikan, penyidik berada pada dua pilihan, melakukan penyidikan secara bersamaan antara tindak pidana pencucian uang dan tindak pidana asal atau hanya menyidik tindak pidana pencucian uang. Demikian juga dalam penyusunan surat dakwaan, penuntut umum berada pada dua pilihan, mendakwa secara bersamaan antara tindak pidana asal dan tindak pidana pencucian uang atau hanya mendakwa tindak pidana pencucian uang. 
Hal demikian juga dihadapi oleh hakim pada saat membuktikan unsur tindak pidana, hakim berada pada dua pilihan, membuktikan tindak pidana asal terlebih dahulu dan dilanjutkan dengan membuktikan tindak pidana pencucian uang, jika keduanya didakwakan secara bersamaan, atau hanya membuktikan tindak pidana pencucian uang saja, karena tindak pidana asal tidak didakwakan.

Berkenaan dengan permasalahan di atas, terdapat satu putusan yang menarik untuk dikaji dan dianalisis, putusan tersebut adalah Putusan Nomor 57/Pid.Sus/2014/PN.Slr. Terdakwa dalam putusan ini adalah R (48 tahun), seorang pedagang pupuk dari Kabupaten Selayar. Perdagangan pupuk yang dilakukan $\mathrm{R}$ merupakan hasil penyelundupan dari Malaysia yang dibawa melalui kapal menuju Flores, Nusa Tenggara Timur untuk dijual. Hasil dari penjualan pupuk tersebut ditransfer melalui rekening pinjaman kepada orang lain atas nama AR dengan Nomor Rekening 0257-01-006306603 Bank BRISelayar. Transfertersebut dilakukan dua kali, yaitu: pertama, pada tanggal 2 Januari 2014 sebesar Rp54.000.000,-Kedua, pada tanggal 3 Januari 2014 sebesar Rp75.000.000,- Jadi jumlah keseluruhan uang yang ditransfer teman R ke rekening AR berjumlah Rp129.000.000,-

Berdasarkan apa yang dilakukan $\mathrm{R}$, penuntut umum mendakwanya dengan bentuk surat dakwaan subsider, primer Pasal 3 UndangUndang Nomor 8 Tahun 2010, subsider Pasal 4 Undang-Undang Nomor 8 Tahun 2010.

Hakim mempertimbangkan bahwa dakwaan primer Pasal 3 Undang-Undang Nomor 8 Tahun 2010 tidak terbukti dengan pertimbangannya bahwa perbuatan yang dilakukan terdakwa tidak tergolong sebagai perbuatan aktif, sementara Pasal 3 diperuntukkan bagi pelaku aktif. Sedangkan dakwaan subsider Pasal 4 Undang-Undang Nomor 8 Tahun 2010, hakim mempertimbangkan bahwa unsur Pasal 4 telah terpenuhi dan terbukti dengan pertimbangan bahwa terdakwa yang meminjam rekening AR dan menyuruh temannya untuk mentransfer uang yang diduga harta hasil tindak pidana penyelundupan pupuk ke rekening BRI milik AR.

Hal menarik untuk dianalisis dari uraian di atas, mengenai penentuan bentuk surat dakwaan dalam tindak pidana pencucian uang dan pembuktian unsur tindak pidana pencucian. Penuntut umum menyusun surat dakwaannya dengan bentuk subsider, primer Pasal 3 UndangUndang Nomor 8 Tahun 2010, sedangkan subsider Pasal 4 Undang-Undang Nomor 8 Tahun 2010. Antara tindak pidana pencucian uang dan tindak pidana asal memiliki hubungan yang erat, meskipun keduanya berdiri sendiri-sendiri. Sementara terhadap pembuktian unsur tindak pidana pencucian uang, hakim membuktikannya tanpa terlebih dahulu membuktikan tindak pidana asalnya. Bahkan hakim menyatakan terdakwa terbukti melakukan tindak pidana pencucian uang "meskipun tindak pidana asalnya tidak dibuktikan terlebih dahulu."

\section{B. Rumusan Masalah}

Setelah meyimak latar belakang di atas dapat dirumuskan beberapa permasalahan sebagai berikut:

1. Mengapa penentuan bentuk surat dakwaan terhadap tindak pidana pencucian uang dalam Putusan Nomor 57/PID.SUS/2014/ PN.SLR menjadi penting?

2. Bagaimanakah hakim membuktikan unsur tindak pidana pencucian uang dalam 
Putusan Nomor 57/PID.SUS/2014/PN.SLR jika tindak pidana asal tidak didakwakan?

\section{Tujuan dan Kegunaan}

Setiap penelitian pasti memiliki tujuan sebagai suatu sasaran yang ingin dicapai, adapun tujuan dari penelitian ini adalah:

1. Mengetahui dan menganalisa penentuan bentuk surat dakwaan terhadap tindak pidana pencucian uang dalam Putusan Nomor 57/PID.SUS/2014/PN.SLR menjadi penting.

2. Mengetahui dan menganalisa hakim dalam membuktikan unsur tindak pidana pencucian uang dalam Putusan Nomor 57/ PID.SUS/2014/PN.SLR jika tindak pidana asal tidak didakwakan.

Selain tujuan tentunya penelitian ini memiliki kegunaan atau manfaat, adapun kegunaan dari penelitian ini adalah:

1. Secara teoritis, penelitian ini dapat memberi sumbangsih pemikiran tentang karakteristik tindak pidana pencucian uang, serta hubungannya dengan tindak pidana asal.

2. Secara praktis, penelitian ini dapat dijadikan acuan oleh penegak hukum, baik pada tingkat penyidikan, penuntutan maupun pada saat pemeriksaan di sidang pengadilan dalam perkara tindak pidana pencucian uang.

\section{Tinjauan Pustaka}

Istilah tindak pidana pencucian uang berasal dari terjemahan money laundering, dalam bahasa Indonesia diartikan pencucian uang. Steel menceritakan bahwa istilah money laundering awalnya dari tempat usaha pencucian pakaian secara otomatis di AS yang disebut dengan laundromats. Usaha yang berkedok pencucian pakaian otomatis ini dipilih oleh para mafia untuk menyamarkan uang hasil tindak pidana yang dilakukannya menjadi seolah-olah uang yang sah (Darwin, 2012: 12). Namun, menurut Robinson cerita yang demikian hanyalah cerita bohong, menurutnya pencucian uang bukanlah yang seperti disebutkan di atas akan tetapi penempatan uang hasil kejahatan melalui sirkulasi transaksi yang akhirnya uang hasil kejahatan tersebut seolah-olah menjadi uang yang sah (Sjahdeini, 2007: 6).

Menurut Willing pengertian pencucian uang adalah proses penyembunyian keberadaan, sumber tindak sah, atau aplikasi pendapatan tidak sah, sehingga pendapatan itu menjadi nampak sah. Demikian juga menurut Fraser, pencucian uang adalah sebuah proses yang sungguh sederhana di mana uang kotor diproses atau dicuci melalui sumber yang sah atau bersih sehingga orang dapat menikmati keuntungan tidak halal itu dengan aman (Harmadi, 2011: 26).

Menurut Bucy mendefinisikan pencucian uang adalah perahasiaan dari keberadaan, sumber yang tidak sah tentang dana gelap sedemikian rupa sehingga dana tersebut akan tampak sah jika ditemukan. Tidak berbeda dengan pendapat Chaikin yang mendefinisikan pencucian uang sebagai suatu proses dengan mana satu penyembunyian atau penyamaran sumber, disposisi, pergerakan, atau uang kepemilikan untuk alasan apapun juga (Harmadi, 2011: 26).

Proses penyamaran atau penyembunyian atas uang hasil tindak pidana tersebut dapat dilakukanmelalui tiga tahapan(Uly \& Tanya, 2009: 
13-17), yaitu: 1) placemen, yakni kegiatan untuk menempatkan uang hasil tindak pidana ke sistem keuangan atau non-sistem keuangan; 2) layering, yakni kegiatan pelapisan dengan mentransfer uang hasil tindak pidana yang telah diletakkan di sistem keuangan (bank) lalu ditransfer ke sistem keuangan yang lain (bank), baik di lingkup dalam negeri maupun di luar negeri; dan 3) integration, yakni kegiatan penyatuan uang hasil tindak pidana yang telah diproses dalam sistem keuangan ditarik dan dimasukkan ke perusahaan yang sah.

Undang-Undang Nomor 8 Tahun 2010 Tentang Pencegahan dan Pemberantasan Tindak Pidana Pencucian Uang mempertegas pengertian tindak pidana pencucian uang secara yuridis, pada Pasal 1 angka (1) dinyatakan bahwa: "Pencucian uang adalah segala perbuatan yang memenuhi unsur-unsur tindak pidana sesuai dengan ketentuan dalam undang-undang ini," yakni Pasal 3, Pasal 4, dan Pasal 5 Undang-Undang Nomor 8 Tahun 2010.

Menurut Husein pada saat sosialisasi Undang-Undang Nomor 8 Tahun 2010 di Fakultas Hukum Universitas Jember tahun 2011 menyatakan bahwa Pasal 3 merupakan delik aktif, sedangkan Pasal 5 merupakan delik pasif. Penentuan yang demikian dapat memudahkan penegak hukum dalam membuktikan perbuatan tindak pidana pencucian uang. Sedangkan Pasal 4 merupakan delik baru untuk menjerat pelaku yang menyembunyikan asal usul, sumber dan lainya, tetapi pelaku bukanlah pelaku tindak pidana asal (Husein, 2011).

Dalam konteks pidana materiil, UndangUndang Nomor 8 Tahun 2010 sepintas bersifat kontradiktif, Pasal 69 menyatakan: "Untuk dapat dilakukan penyidikan, penuntutan, dan pemeriksaan di sidang pengadilan terhadap tindak pidana pencucian uang tidak wajib dibuktikan terlebih dahulu tindak pidana asalnya."

Berdasarkan pasal ini dapat disimpulkan bahwa perkara tindak pidana pencucian uang dapat dilakukan penyidikan juga penuntutan bahkan dilakukan proses persidangan meskipun tindak pidana asal dari tindak pidana pencucian uang tidak dibuktikan terlebih dahulu. Dengan kata lain, tindak pidana pencucian uang dapat dilakukan penyidikan, penuntutan dan pemeriksaan di sidang pengadilan secara mandiri tanpa bersamaan dengan tindak pidana asal.

Pasal 75 Undang-Undang Nomor 8 Tahun 2010 menyatakan: "Dalam hal penyidikan menemukan bukti permulaan yang cukup terjadinya tindak pidana pencucian uang dan tindak pidana asal, penyidik menggabungkan penyidikan tindak pidana asal dengan penyidikan tindak pidana pencucian uang dan memberitahukannya kepada PPATK." Pasal ini memberi peluang kepada tindak pidana pencucian uang dan tindak pidana asal dilakukan penyidikan secara bersamaan, dengan syarat apabila telah ada bukti permulaan yang cukup terhadap tindak pidana asal. Pasal tersebut juga berimplikasi pada penyusunan bentuk surat dakwaan oleh penuntut umum, berpijak pada pasal tersebut, bentuk surat dakwaan yang disusun penuntut umum berbentuk kumulatif, yakni mendakwa secara bersama antara tindak pidana asal dan tindak pidana pencucian uang.

Dua pasal di atas seolah-olah bersifat kontradiktif, Pasal 69 memperkenankan untuk dilakukan penyidikan, bahkan penuntutan apalagi pemeriksaan di sidang pengadilan terhadap tindak pidana pencucian uang meskipun tidak dibuktikan terlebih dahulu tindak pidana asalnya. Sedangkan Pasal 75 juga memperkenankan dilakukan 
penyidikan secara bersamaan antara tindak pidana pencucian uang dan tindak pidana asal, dengan syarat penyidik telah menemukan bukti permulaan yang cukup terhadap tindak pidana asal. Harus dipahami bahwa keberadaan Pasal 69 tidak bisa berdiri sendiri, harus disandingkan dengan Pasal 77 dan Pasal 78 (pembalikan beban pembuktian). Perumus Undang-Undang Nomor 8 Tahun 2010 beranggapan bahwa pada akhirnya tindak pidana pencucian uang tetap didasari oleh adanya tindak pidana asal, maka pada tahap pemeriksaan di sidang pengadilan sebagaimana diatur dalam Pasal 77: "untuk kepentingan pemeriksaan di sidang pengadilan terdakwa wajib membuktikan bahwa harta kekayaannya bukan merupakan hasil tindak pidana."

Terdakwa tindak pidana pencucian uang wajib membuktikan harta kekayaannya bukan merupakan hasil tindak pidana alias tindak pidana asal. Selain itu, Pasal 69 Undang-Undang Nomor 8 Tahun 2010 berfungsi sebagai perampasan aset dengan cara keperdataan (civil forfectur) (Utomo, 2013: 62) yang dikhususkan terhadap tindak pidana illicit enrichment, yakni pejabat negara yang memiliki harta kekayaan melebihi dari profil pekerjaan dan penghasilannya, sehingga harta kekayaan yang lebih tersebut diduga hasil dari tindak pidana. Namun sangat disayangkan tindak pidana tersebut belum diberlakukan di Indonesia, sehingga Pasal 69 tidak berfungsi (Atmasasmita, 2013: 24).

\section{METODE}

Metode dalam suatu penelitian menjadi hal yang mutlak harus ada, sebagaimana yang disampaikan oleh Soekanto(2010:6) “metodologi merupakan suatu unsur yang mutlak harus ada di dalam penelitian dan pengembangan ilmu pengetahuan." Demikian juga yang disampaikan Ibrahim (2006: 26), terdapat dua hal yang sangat penting sebelum melakukan penelitian ilmiah, pertama, menguasai dasar-dasar ilmu pengetahuan yang akan ditelitinya, dan kedua, menguasai metodologi disiplin ilmu pengetahuan yang akan diteliti.

Penelitian yang penulis lakukan adalah penelitian terhadap Putusan Nomor 57/PID. SUS/2014/PN.SLR yang penulis peroleh dari Direktori Putusan Mahkamah Agung. Putusan ini diidentifikasi masalah hukum yang terkandung di dalamnya lalu dilakukan penalaran hukum dan menganalisanya untuk dipecahkan melalui kaidah-kaidah hukum yang berlaku dan relevan dengan permasalahan hukum yang ingin dipecahkan, sehingga luaran dari hasil analisisnya berbentuk preskripsi. Tipe penelitian yang demikian menurut Marzuki (2016: 60) disebut dengan penelitian yuridis normatif.

Untuk menganalisis permasalahan hukum yang ada dalam Putusan Nomor 57/PID. SUS/2014/PN.SLR, penulis menggunakan dua pendekatan, pertama, pendekatan perundangundangan (statute approach), pendekatan ini dilakukan dengan cara menelaah undangundang dan regulasi yang berhubungan dengan permasalahan hukum yang penulis angkat. Kedua, pendekatan konseptual (conceptual approach), pendekatan yang menggunakan pandangan-pandangan dan doktrin-doktrin yang berkembang di dalam ilmu hukum yang membentuk pengertian ilmu hukum, konsepkonsep hukum dan asas-asas hukum. Untuk menganalisis rumusan masalah yang menjadi objek penelitian dibutuhkan bahan hukum, baik yang bersifat bahan hukum primer maupun yang bersifat bahan hukum sekunder. Bahan hukum primer merupakan bahan hukum yang bersifat 
autoritatif yakni memiliki otoritas. Sedangkan bahan hukum primer terdiri dari perundangundangan, risalah pembuatan perundangundangan dan putusan hakim (Marzuki, 2016: 181).

Bahan hukum primer dalam penelitian ini adalah KUHAP, Undang-Undang Nomor 8 Tahun 2010, dan Putusan Nomor 57/PID. SUS/2014/PN.SLR. Sedangkan bahan hukum sekunder adalah semua publikasi tentang hukum yang bukan merupakan dokumen-dokumen resmi, seperti buku-buku teks, jurnal hukum, dan komentar-komentar atas putusan (Marzuki, 2016: 181). Bahan hukum sekunder dari penelitian ini terdiri dari buku-buku hukum, jurnal yang ada hubungan dengan rumusan masalah.

\section{HASIL DAN PEMBAHASAN}

\section{A. Urgensi Penentuan Bentuk Surat Dakwaan terhadap Tindak Pidana Pencucian Uang dalam Putusan Nomor 57/PID.SUS/2014/PN.SLR}

Penuntut umum memiliki kewenangan mutlak dalam merumuskan surat dakwaan sebagai tindak lanjut dari proses penyidikan untuk dilimpahkan ke pengadilan agar diperiksa dan diputus. Pasal 140 KUHAP menyatakan: "Dalam hal penuntut umum berpendapat bahwa dari hasil penyidikan dapat dilakukan penuntutan, ia dalam waktu secepatnya membuat surat dakwaan."

Menurut Harahap (2010: 386), pasal di atas merupakan bagian dari kegiatan penuntutan, kegiatan tersebut terdiri dari tahapan proses pemeriksaan atas suatu tindak pidana yang dimulai dari tahapan pemeriksaan penyidikan ke tingkat proses pemeriksaan di sidang pengadilan yang dilakukan oleh hakim guna mengambil putusan atas perkara tindak pidana. Akan tetapi sebelum sampai pada proses pelimpahan dan pemeriksaan di sidang pengadilan, penuntut umum terlebih dulu mempelajari berkas hasil penyidikan, apakah telah lengkap atau belum. Jika telah dinyatakan lengkap, penuntut umum mempersiapkan surat dakwaan dan surat pelimpahan perkara kepada pengadilan. Artinya, sebelum suatu perkara pidana dilimpahkan dan diperiksa di pengadilan, tugas pokok penuntut umum adalah mempersiapkan surat dakwaan. Pada hakikatnya fungsi surat dakwaan adalah sebagai dasar bagi hakim dalam memeriksa dan memutus. Harahap (2010: 389) mengatakan bahwa surat dakwaan sebagai landasan dan titik tolak pemeriksaan terdakwa dalam sidang pengadilan.

Hamzah (2010: 167) juga menyatakan: bahwa surat dakwaan merupakan dasar penting hukum acara pidana karena berdasarkan hal yang dimuat dalam surat dakwaan, hakim akan memeriksa. Hal yang sama diungkapkan oleh Muhammad (2007: 83), setiap penuntut umum melimpahkan perkara ke pengadilan selalu disertai dengan surat dakwaan sebagai dasar pemeriksaan yang dilakukan oleh hakim di pengadilan.

Penyusunan surat dakwaan dalam perkara tindak pidana pencucian uang tidaklah mudah. Karena tindak pidana pencucian uang memiliki karakteristik yang berbeda dengan tindak pidana lain, tindak pidana ini terdiri dari dua tindak pidana, pertama, tindak pidana asal secara limitatif disebutkan dalam Pasal 2 UndangUndang Nomor 8 Tahun 2010, dari tindak pidana asal inilah harta kekayaan yang tidak sah dihasilkan. Kedua, tindak pidana pencucian uang, yakni tindak pidana yang menyembunyikan atau menyamarkan harta kekayaan yang dihasilkan 
oleh tindak pidana asal agar seolah-olah menjadi harta kekayaan yang sah.

Dua tindak pidana tersebut memiliki hubungan yang erat, sehingga "seolah-olah" tidak akan terjadi tindak pidana pencucian uang jikalau tidak didahului oleh tindak pidana asal terlebih dahulu. Hal tersebut berdampak pada penyusunan surat dakwaan, apakah antara tindak pidana pencucian uang dengan tindak pidana asal didakwa secara bersamaan atau hanya tindak pidana pencucian uang yang didakwakan tanpa tindak pidana asal.

Harus diingat bahwa penentuan atau penyusunan surat dakwaan dalam tindak pidana pencucian uang memiliki konsekuensi kepada hakim untuk menentukan sistem pembuktian yang telah diatur secara khusus dalam UndangUndang Nomor 8 Tahun 2010. Jika dakwaan yang disusun menggabungkan antara tindak pidana pencucian uang dan tindak pidana asal, maka pembuktiannya menggunakan sistem pembuktian yang diatur dalam KUHAP, namun jika dakwaan yang disusun hanya mendakwa tindak pidana pencucian uang, maka pembuktiannya menerapkan sistem pembalikan beban pembuktian. Pada Putusan Nomor 57/PID. SUS/2014/PN.SLR penuntut umum menyusun surat dakwaan berbentuk subsider, primer Pasal 3 Undang-Undang Nomor 8 Tahun 2010, yaitu:

"Setiap orang yang menempatkan, mentransfer, mengalihkan, membelanjakan, membayarkan, menghibahkan, menitipkan, membawa ke luar negeri, mengubah bentuk, menukarkan dengan mata uang atau surat berharga atau perbuatan lain atas harta kekayaan yang diketahuinya atau patut diduganya merupakan hasil tindak pidana sebagaimana dimaksud dalam Pasal 2 ayat (1) dengan tujuan menyembunyikan atau menyamarkan asal usul harta kekayaan dipidana karena tindak pidana pencucian uang dengan pidana penjara paling lama 20 tahun dan denda paling banyak Rp10.000.000.000,-"

Sedangkan subsider Pasal 4 UndangUndang Nomor 8 Tahun 2010, yaitu:

"Setiap orang yang menyembunyikan atau menyamarkan asal usul, sumber, lokasi, peruntukan, pengalihan hak-hak, atau kepemilikan yang sebenarnya atas harta kekayaan yang diketahuinya atau patut diduganya merupakan hasil tindak pidana sebagaimana dimaksud dalam Pasal 2 ayat (1) dipidana karena tindak pidana pencucian uang dengan pidana penjara paling lama 20 tahun dan denda paling banyak Rp5.000.000.000,-"

Jikalau merujuk pada ketentuan hukum acara yang diatur dalam Undang-Undang Nomor 8 Tahun 2010, penuntut umum diberi kewenangan yang bebas, mendakwa pelaku tindak pidana pencucian uang dengan hanya mendakwa tindak pidana pencucian uang atau mendakwa bersamaan dengan tindak pidana asal, sebagaimana diatur dalam Pasal 69 dan Pasal 75 Undang-Undang Nomor 8 Tahun 2010.

Pasal 69 Undang-Undang Nomor 8 Tahun 2010 menyatakan bahwa: "Untuk dilakukan penyidikan, penuntutan, dan pemeriksaandisidang pengadilan terhadap tindak pidana pencucian uang tidak wajib dibuktikan terlebih dahulu tindak pidana asalnya." Pasal ini menyatakan bahwa proses penyidikan, penuntutan bahkan pemeriksaan di sidang pengadilan terhadap tindak pidana pencucian uang tidak wajib dibuktikan terlebih dahulu tindak pidana asalnya. Artinya, penyidik diperkenankan melakukan penyidikan terhadap tindak pidana pencucian uang meskipun tidak dibuktikan terlebih dahulu tindak pidana asalnya, demikian juga penuntut umum dan hakim dalam melakukan penuntutan dan pememeriksa di sidang pengadilan. 
Jika merujuk pada Pasal 75 Undang-Undang Nomor 8 Tahun 2010 yang menyatakan: "Dalam hal penyidik menemukan bukti permulaan yang cukup terjadinya tindak pidana pencucian uang dan tindak pidana asal, penyidik menggabungkan penyidikan tindak pidana asal dengan penyidikan tindak pidana pencucian uang dan memberitahukannya kepada PPATK." Penyidik dapat melakukan penyidikan secara bersamaan antara tindak pidana asal dengan tindak pidana pencucian uang, demikian pula penuntut umum, juga dapat menyusun surat dakwaan secara bersamaan (kumulasi) antara tindak pidana asal dan tindak pidana pencucian uang.

Tidak menjadi persoalan jikalau penuntut umum dalam menyusun surat dakwaan dalam Putusan Nomor 57/PID.SUS/2014/PN.SLR hanya mendakwa pasal tindak pidana pencucian uang tanpa menyertakan tindak pidana asal, sebagaimana diatur dalam Pasal 69 UndangUndang Nomor 8 Tahun 2010. Namun demikian, hakim harus menerapkan Pasal 77, artinya hakim dapat menerapkan pembalikan beban pembuktian. Mengapa demikian karena eksistensi Pasal 69 memiliki korelasi dengan Pasal 77.

Pasal 69 Undang-Undang Nomor 8 Tahun 2010 harus dipahami secara konprehensif oleh para penegak hukum, khususnya hakim, agar penerapannya benar-benar sesuai dengan rasio legis pada saat pasal tersebut dirumuskan. Sebagaimana kritik yang disampaikan Atmasasmita (2013: 7) terhadap penerapan hukum tindak pidana pencucian uang:

"Merujuk kelemahan-kelemahan dalam penanganan perkara tindak pidana pencucian uang sehingga harus terjadi perubahan kedua kali, menurut pendapat saya, bukanlah perubahan undang-undang yang menjadi masalah dalam pembentukan undang-undang ini (Undang-Undang
Nomor 8 Tahun 2010, penulis), melainkan pada pemahaman dan persepsi para ahli hukum pidana dan praktisi hukum terhadap filosofi, visi, misi, dan karakter tindak pidana pencucian uang."

Pasal 69 Undang-Undang Nomor 8 Tahun 2010 sebenarnya mengatur tentang perampasan aset dengan cara keperdataan (civil forfeiture/in rem). Menurut Atmasasmita (2013: 23), hakikat pasal tersebut adalah untuk merampas aset hasil tindak pidana asal (yang dicuci) melalui keperdataan (civil forfeiture/in rem), selama ini perampasan aset yang selalu digunakan adalah in personam/criminal forfeiture, perampasan aset setelah adanya putusan hakim dalam perkara pidana. Karena ketentuan tersebut menegaskan bahwa sasaran Undang-Undang Nomor 8 Tahun 2010 adalah bukan pada perbuatan (kesalahan) terdakwa, melainkan pada harta kekayaan yang diduga berasal dari atau terkait dengan tindak pidana asal.

$$
\text { Model perampasan seperti ini }
$$
menitikberatkan pada "benda" (thing), di mana benda dalam konteks ini merupakan fiksi hukum yang menegaskan bahwa, benda tersebut (harta hasil tindak pidana asal) dianggap sebagai "subjek hukum" yang memiliki kesadaran atau niat, layaknya seperti seorang manusia sehingga patut dipertanggungjawabkan status hukumnya (Atmasasmita, 2010: 59).

Model perampasan aset yang demikian, sebagaimana yang dianut dalam Pasal 69 Undang-Undang Nomor 8 Tahun 2010 didasari oleh pandangan yang mengatakan "tidak seseorangpun berhak memiliki kekayaan yang tidak patut dimilikinya." Pandangan ini tercermin dari beberapa istilah, crime shouldn't pay; unjust enrichment atau illicit enrichment; no one benifit from his own wrongdoing. Teori yang melandasi 
pandangan ini disebut rational choice theory (Atmasasmita, 2010: 58). Sehingga original intent antara tindak pidana asal dengan tindak pidana pencucian uang memiliki perbedaan. Original intent pada tindak pidana asal masih bertumpu pada segi perbuatan dan pembuatnya (daad-dader strafrecht). Sedangkan objek tindak pidana pencucian uang adalah harta kekayaan yang diduga berasal atau diperoleh dari tindak pidana asal.

Perbedaan objek kedua tindak pidana tersebut berdampak terhadap pembuktian secara normatif, yaitu pembuktian atas tindak pidana asal adalah perbuatan dan kesalahan pelaku tindak pidana asal, sedangkan pembuktian atas tindak pidana pencucian uang adalah pada perolehan kekayaan yang diduga berasal dari tindak pidana. Dengan demikian, tindak pidana pencucian uang yang didakwakan secara mandiri tanpa bersamaan dengan tindak pidana asalnya lebih kepada perampasan aset (harta kekayaan yang dicuci) sarana keperdataan (civil forfeiture) dengan didukung oleh pembalikan beban pembuktian. Di samping itu, tindak pidana pencucian uang yang didakwa secara mandiri tanpa bersamaan dengan tindak pidana asalnya tidak membuktikan perbuatan dan kesalahan pelaku tindak pidana pencucian uang.

Sangat disayangkan, hakim dalam Putusan Nomor 57/PID.SUS/2014/PN.SLR tidak menerapkan pembalikan beban pembuktian sebagaimana diatur dalam Pasal 77 UndangUndang Nomor 8 Tahun 2010, meskipun pembalikan beban pembuktian tersebut hanya untuk merampas aset hasil tindak pidana melalui keperdataan, dan pembalikan beban pembuktian tersebut tidak membuktikan kesalahan R sebagai terdakwa.
Hakim menerapkan sistem pembuktian sebagaimana yang diatur dalam KUHAP, padahal penerapan pembuktian sebagaimana diatur dalam KUHAP apabila penuntut umum mendakwa terdakwa dengan pasal tindak pidana pencucian uang dengan tindak pidana asal (kumulatif). Jikalau hakim menerapkan sistem pembuktiannya dengan menggunakan sistem pembuktian sebagaimana diatur dalam KUHAP, maka penuntut umum dalam mendakwa terdakwa pelaku tindak pidana pencucian uang dalam Putusan Nomor 57/PID.SUS/2014/PN.SLR dengan bentuk surat dakwaan kumulatif, dakwaan pertama terdakwa didakwa dengan tindak pidana penyelundupan, karena terdakwa telah diduga melakukan tindak pidana penyelundupan pupuk matahari dari negara Malaysia ke Indonesia. Sedangkan dakwaan kedua, terdakwa didakwa dengan pasal tindak pidana pencucian uang baik Pasal 3 atau Pasal 4 Undang-Undang Nomor 8 Tahun 2010.

Hakikatnya tindak pidana pencucian uang tidak berdiri sendiri sebagaimana tindak pidana lainnya, melainkan tindak pidana ini berhubungan dengan tindak pidana lainnya (tindak pidana asal/predicative offence), sehingga tepat jika dinyatakan bahwa tindak pidana pencucian uang merupakan condition sine qua non (berhubungan) dengan tindak pidana asal sebagaimana telah diatur dalam Pasal 2 ayat (1) Undang-Undang Nomor 8 Tahun 2010 (Atmasasmita, 2013: 7).

Demikian juga yang disampaikan oleh Garnasih,tindakpidanapencucianuangmerupakan kejahatan yang mempunyai karakteristik berbeda dengan jenis kejahatan pada umumnya, terutama bahwa tindak pidana ini bukan merupakan tindak pidana tunggal tetapi kejahatan ganda. Namun demikian antara tindak pidana asal dan tindak pidana pencucian uang merupakan kejahatan yang 
berdiri sendiri (Garnasih, 2013: 4). Artinya tindak pidana pencucian uang memiliki karakter khusus, bahwa tindak pidana ini sangat berhubungan dengan tindak pidana asal, meskipun tindak pidana pencucian uang dengan tindak pidana asalnya berdiri sendiri-sendiri.

Hubungan antara tindak pidana pencucian uang dengan tindak pidana asalnya tidak memiliki satu kehendak jahat atau mens rea yang sama, karena kehendak melakukan tindak pidana asal yang diwujudkan dalam perbuatannya berbeda dengan kehendak untuk melakukan tindak pidana pencucian uang yang diatur dalam Pasal 3, Pasal 4, dan Pasal 5 Undang-Undang Nomor 8 Tahun 2010.

Menurut Atmasasmita (2013: 7), dengan alasan tersebut tindak pidana pencucian uang tidak termasuk tindak pidana berlanjut (vogezette handeling), karena tidak memiliki niat jahat yang sama. Namun kedua tindak pidana tersebut merupakan tindak pidana yang berbarengan (concursus realis), yakni dua tindak pidana yang berdiri sendiri dan ada hubungannya satu sama yang lain. Dari sisi hukum pidana formil, adanya tindak pidana dalam bentuk concursus (berbarengan) menuntut penuntut umum dalam menyusun surat dakwaannya berbentuk kumulasi, sebagai konsekuensi dari berbarengan tindak pidana tersebut sebagai aspek pemidanaan.

Pelanggaran atas pengajuan dakwaan bentuk kumulatif dalam perkara yang mengandung concursus (berbarengan) tindak pidana, dengan sendirinya merupakan cara yang tidak tepat dalam menjatuhkan hukuman. Karena setiap bentuk peristiwa pidana yang mengandung concursus (berbarengan) tindak pidana, sudah ditentukan cara atau sistem pemidanaannya (Harahap, 2010: 409).
Implikasi hubungan tindak pidana asal dengan tindak pidana pencucian uang terhadap penyusunan surat dakwaan, sebagaimana disampaikan oleh Garnasih, bahwa tindak pidana pencucian uang dengan tindak pidana asalnya harus disusun dakwaan dalam bentuk kumulatif, karena tujuan pelaku memproses tindak pidana pencucian uang adalah untuk menyembunyikan atau menyamarkan hasil dari predicate offence (tindak pidana asal) agar tidak diketahui asal usulnya untuk selanjutnya dapat digunakan, jadi bukan untuk tujuan menyembunyikan saja tapi merubah performance atau asal usul hasil kejahatan untuk tujuan selanjutnya dan menghilangkan hubungan langsung dengan tindak pidana asalnya.

Dengan demikian jelas bahwa berbagai kejahatan keuangan (interprise crimes) hampir pasti akan dilakukan pencucian uang atau paling tidak harus sesegera mungkin dilakukan pencucian uang untuk menyembunyikan harta hasil tindak pidana asal itu agar terhindar dari penuntutan petugas (Garnasih, 2013: 4).

Dalam praktik, sebagaimana yang ditulis oleh Sapardjaja (2013: 5-6), bahwa akhir-akhir ini perkara tindak pidana pencucian uang banyak masuk ke pengadilan. Dakwaan tindak pidana pencucian uang menjadi dakwaan kumulasi kedua di samping dakwaan terhadap tindak pidana asalnya. Beberapa contoh perkara yang telah diputus oleh pengadilan negeri, pengadilan tinggi, dan Mahkamah Agung antara lain:

1. Putusan Nomor 507 K/PID.SUS/2009 yang berhubungan dengan Putusan Nomor 498 K/PID.SUS/2009 dan Nomor 499 K/ PID.SUS/2009, dakwaan tindak pidana pencucian uang sebagai dakwaan kumulatif kedua terbukti dengan mudah karena tindak 
pidana asalnya, yaitu penggelapan sebagai dakwaan kesatu dapat dibuktikan;

2. Putusan Nomor 248 K/PID.SUS/2011 yang berhubungan dengan Nomor $2486 \mathrm{~K} /$ PID.SUS/2011 dan Nomor 2480 K/PID. SUS/2011 adalah perkara di mana para terdakwa penerima hasil tindak pidana pembobolan Bank Permata Bandung yang dilakukan oleh orang lain tetapi para terdakwa tersebut mengetahui bahwa harta kekayaan berupa keuntungan 10\% berasal dari transfer fiktif yang diketahuinya berasal dari tindak pidana penipuan;

3. Putusan Nomor $1607 \mathrm{~K} / \mathrm{PID}$. SUS/2012 berasal dari tindak pidana pemalsuan/ pencatatan palsu atas rekening para nasabah yang kemudian ditarik dan ditempatkan dalam rekening terdakwa sendiri, pacarnya, adiknya, padahal uang tersebut bukan kekayaannya sendiri yang dibelanjakan dalam bentuk mobil mewah dan properti lainnya. Jaksa penuntut umum berhasil melakukan pembuktian bahwa penarikan uang yang ditempatkan dalam rekening pribadi terdakwa dan pihak lainnya sebanyak 117 kali, dan berhasil menelusuri aset yang berasal dari tindak pidana asal.

Berdasarkan uraian di atas, penentuan bentuk surat dakwaan dan pasal yang didakwakan menjadi hal yang penting dalam perkara tindak pidana pencucian uang. Bentuk surat dakwaan dan pasal yang didakwakan terhadap perkara tindak pidana pencucian uang berdampak pada kecermatan hakim dalam memilih sistem pembuktian. Ketepatan dalam menentukan bentuk surat dakwaan dan pasal yang didakwakan menjadi hal yang penting dalam perkara tindak pidana pencucian uang.
B. Pembuktian Unsur Tindak Pidana Pencucian Uang dalam Putusan Nomor 57/PID.SUS/2014/PN.SLR jika Tindak Pidana Asal Tidak Didakwakan

Perumusan tindak pidana dalam suatu undang-undang, terkadang dirumuskan dengan menguraikan unsur-unsur dan elemen dari tindak pidana, terkadang pula hanya dirumuskan dengan menyebutkan kualifikasi tindak pidananya saja. Moeljatno (2009: 71) mengatakan, bahwa rumusan perbuatan beserta sanksinya yang dijumpai dalam aturan pidana dimaksudkan untuk menunjukkan perbuatan-perbuatan mana yang dilarang dan pantang dilakukan. Pada umumnya maksud tersebut dapat dicapai dengan menentukan beberapa elemen, unsur atau syarat yang menjadi ciri atau sifat khas dari larangan tersebut. Sehingga dapat dibedakan dari perbuatan-perbuatan lain yang tidak dilarang.

Perbedaan dari istilah unsur, elemen dan kualifikasi yang menjadi rumusan dari tindak pidana. Menurut Hiariej perbedaan antara unsur dan elemen terletak pada keluasan cangkupan antara elemen dengan unsur. Elemen dalam suatu tindak pidana adalah unsur-unsur yang terdapat dalam suatu tindak pidana, unsur tersebut baik tertulis maupun tidak tertulis dalam rumusan tindak pidana. Sedangkan unsur adalah bestandeel yakni unsur tindak pidana yang secara expressiv verbis tertuang dalam suatu rumusan tindak pidana (Hiariej, 2014: 97).

Para ahli hukum pidana membagi unsur tindak pidana tersebut menjadi dua, pertama, unsur objektif, yakni unsur tindak pidana yang berada di luar diri pelaku tindak pidana. Unsur objektif terdiri dari: 1) perbuatan dan akibat; 2) hal ikhwal atau keadaan yang menyertai perbuatan; 3) keadaan tambahan yang memberatkan pidana; 
dan 4) sifat melawan hukum (Moejatno, 2009: 69). Kedua, unsur subjektif, yakni unsur tindak pidana yang berada dalam diri pelaku tindak pidana. unsur subjektif ini terdiri dari kesengajaan atau kealpaan (dolus atau culpa) dan degradasinya.

Hiariej (2014:97) melanjutkan pendapatnya, perumusan tindak pidana dengan menguraikan unsur-unsur ataupun kualifikasi memiliki fungsi, yaitu: 1) rumusan delik sebagai pengejawantahan dari asas legalitas; dan 2) rumusan tindak pidana berfungsi sebagai unjuk bukti dalam konteks hukum acara pidana. Dengan adanya rumusan tindak pidana dalam bentuk unsur-unsur maupun kualifikasi tindak pidana menjadi hal yang harus dibuktikan dalam persidangan untuk menentukan apakah pelaku dari tindak pidana telah memenuhi unsur-unsur tindak pidana yang telah dilakukan antau tidak. Hal ini nantinya menjadikan dasar bagi hakim dalam menentukan putusannya.

Putusan Nomor 57/PID.SUS/2014/PN.SLR dengan terdakwa $\mathrm{R}$ didakwa oleh penuntut umum dengan dakwaan primer Pasal 3 Undang-Undang Nomor 8 Tahun 2010 dan dakwaan sekunder Pasal 4 Undang-Undang Nomor 8 Tahun 2010. Karena dakwaan primer Pasal 3 dibuktikan oleh hakim dengan menguraikan unsur-unsur Pasal 3 dan membuktikan satu-persatu unsurunsur tersebut. Unsur-unsur Pasal 3 dirumuskan oleh hakim sebagai berikut: 1) setiap orang; 2) yang menempatkan, mentransfer, mengalihkan, membelanjakan, membayarkan, menghibahkan, menitipkan, membawa ke luar negeri, mengubah bentuk, menukarkan dengan mata uang atau surat berharga atau perbuatan lain atas harta kekayaan yang diketahuinya atau patut diduganya hasil tindak pidana sebagaimana dimaksud dalam Pasal 2 ayat (1); dan 3) dengan tujuan menyembunyikan atau menyamarkan asal usul harta kekayaan.
Unsur setiap orang menurut pertimbangan hakim telah terbukti. Sedangkan unsur "yang menempatkan, mentransfer, mengalihkan, membelanjakan, membayarkan, menghibahkan, menitipkan, membawa ke luar negeri, mengubah bentuk, menukarkan dengan mata uang atau surat berharga atau perbuatan lain atas harta kekayaan yang diketahuinya atau patut diduganya hasil tindak pidana sebagaimana dimaksud dalam Pasal 2 ayat (1) menurut hakim tidak terbukti.

Hakim mempertimbangkan bahwa proses transfer harta kekayaan yang diduga dari hasil tindak pidana penyelundupan dilakukan oleh rekan terdakwa di Maumere ke rekening BRI atas nama AR total sebesar Rp129.000.000,- Hal ini menandakan bahwa kegiatan pentransferan ini bukan merupakan sikap aktif dari terdakwa $\mathrm{R}$, namun dari saksi AR yang diminta tolong oleh terdakwa. Jadi transfer tersebut tidak dilakukan oleh terdakwa tetapi dilakukan oleh rekan dan tanpa terdakwa. Sehingga hakim mempertimbangkan bahwa unsur ini tidak terbukti. Karena satu unsur dinyatakan tidak terbukti maka unsur berikutnya tidak dibuktikan oleh hakim, sehingga disimpulkan oleh hakim bahwa tindak pidana pencucian uang sebagaimana diatur dalam Pasal 3 tidak terbukti.

Bentuk surat dakwaan yang disusun oleh penuntut umum berbentuk surat dakwaan subsider, maka hakim memiliki kewenangan untuk membuktikan dakwaan subsider sebagai dakwaan pengganti dari dakwaan primer yang tidak terbukti tersebut. Hakim mengulas dan membuktikan unsur-unsur Pasal 4 UndangUndang Nomor 8 Tahun 2010 sebagai dakwaan subsider sebagai berikut:

1. Unsur setiap orang;

2. Unsurmenyembunyikanataumenyamarkan 
asal usul, sumber, lokasi, peruntukan, pengalihan hak-hak, atau kepemilikan yang sebenarnya atas harta kekayaan yang diketahuinya;

3. Unsur patut diduganya merupakan hasil tindak pidana sebagaimana dimaksud dalam Pasal 2 ayat (1).

Unsur "setiap orang" menurut hakim telah terbukti. Sedangkan unsur "menyembunyikan atau menyamarkan asal usul, sumber, lokasi, peruntukan, pengalihan hak-hak, atau kepemilikan yang sebenarnya atas harta kekayaan yang diketahuinya" berdasarkan fakta dan keadaan yang terungkap di persidangan yang satu dengan yang lain saling bersesuaian antara keterangan saksi-saksi dan keterangan terdakwa (Putusan Nomor 57/PID.SUS/2014//PN.SLR):

- $\quad$ Bahwa pada tanggal 3 Januari 2014 saksi AR melakukan transaksi penarikan uang di Bank BRI, pertama sebesar Rp54.000.000,dan kedua, sebesar Rp75.000.000,-;

- Bahwa sebelum penarikan uang itu terjadi, saksi AR bertemu dengan terdakwa $\mathrm{R}$ di pelabuhan Rauf Rahman Benteng Selayar, lalu terdakwa menanyakan kepada saksi AR memiliki nomor rekening bank karena akan ada orang yang mau mentransfer uang kepada terdakwa dan saksi memberikan nomor rekening BRI-nya kepada terdakwa;

- Bahwa setelah terdakwa mendapat kabar dari rekannya di Maumere uangnya telah ditransfer, terdakwa menyuruh saksi AR untuk mengecek kebenaran adanya transfer uang tersebut. Ternyata, transfer uang dari rekan terdakwa memang ada dan saksi mengambil uang tersebut dan menyerahkan kepada terdakwa dan penarikan itu dilakukan dua kali. Setelah uang tersebut diserahkan kepada terdakwa oleh saksi, maka saksi meninggalkan terdakwa tanpa meminta dan memperoleh imbalan dari terdakwa.

Uang yang ditransfer dari teman terdakwa di Flores/Maumere kepada melalui rekening saksi AR diduga merupakan uang hasil dari penjualan pupuk cap Matahari yang dilakukan oleh terdakwa di Flores/Maumere Nusa Tenggara Timur. Dari fakta-fakta tersebut, hakim mempertimbangkan bahwa unsur "menyembunyikan atau menyamarkan asal usul, sumber, lokasi, peruntukan, pengalihan hak-hak, atau kepemilikan yang sebenarnya atas harta kekayaan yang diketahuinya" telah terbukti.

Unsur "patut diduganya merupakan hasil tindak pidana sebagaimana dimaksud dalam Pasal 2 ayat (1) menurut pembuktian dan pertimbangan hakim telah terbukti. Bahwa harta kekayaan yang ditransfer oleh rekan terdakwa di Flores/Maumere merupakan hasil tindak pidana di bidang kelautan dan perikanan. Karena terdakwa telah mengakui beberapa kali pernah ke Batam sebagaimana tiket pesawat Lion Air pada tanggal 06 Februari 2012 bersama P, M, S, dan A via Ujung Pandang transit Jakarta menuju Batam. Serta dalam Berita Acara Penyidik yang telah diakui oleh terdakwa, bahwa terdakwa melakukan transaksi memesan barang yang patut diduga adalah pupuk cap Matahari dari Malaysia. Sebelum menganalisa pembuktian yang dilakukan hakim terhadap "unsur diketahuinya atau patut diduganya merupakan hasil tindak pidana sebagaimana dimaksud dalam Pasal 2 ayat (1), di mana tindak pidana asalnya, yakni tindak pidana penyelundupan pupuk atau tindak pidana di bidang kelautan dan perikanan tidak didakwakan dan tidak dibuktikan, terdapat beberapa hal yang sangat penting untuk dianalisa. 
Pertama, mengenai penguraian unsur Pasal 3 dan Pasal 4 Undang-Undang Nomor 8 Tahun 2010. Hakim dalam menguraikan unsur-unsur Pasal 3 dan Pasal 4 tersebut kurang begitu sesuai dengan prinsip unsur-unsur tindak pidana, hakim dalam menguraikan unsur yang didakwakan terlalu bersifat umum sehingga pembuktiannya kurang begitu detail. Seharusnya uraian unsur Pasal 3 adalah sebagai berikut:

1. Unsur setiap orang;

2. Menempatkan, mentransfer, mengalihkan, membelanjakan, membayarkan, menghibahkan, menitipkan, membawa ke luar negeri, mengubah bentuk, menukarkan dengan mata uang atau surat berharga atau perbuatan lain (bersifat alternatif);

3. Unsur harta kekayaan;

4. Unsur diketahuinya atau patut diduganya hasil tindak pidana sebagaimana dimaksud dalam Pasal 2 ayat (1); dan

5. Unsur dengan tujuan menyembunyikan atau menyamarkan asal usul harta kekayaan.

Sedangkan ulasan unsur Pasal 4 UndangUndang Nomor 8 Tahun 2010 adalah sebagai berikut:

1. Unsur setiap orang;

2. Unsurmenyembunyikan ataumenyamarkan asal usul, sumber, lokasi, peruntukan, pengalihan hak-hak, atau kepemilikan yang sebenarnya;

3. Unsur harta kekayaan;

4. Unsur diketahuinya atau patut diduganya merupakan hasil tindak pidana sebagaimana dimaksud dalam Pasal 2 ayat (1).
Kedua, tipologi yang dilakukan oleh terdakwa dan tipologi yang dilakukan oleh rekan terdakwa di Flores/Maumere Nusa Tenggara Timur yang mentransfer uang milik terdakwa melalui rekening saksi AR merupakan tahapan yang berbeda dalam tahapan tindak pidana pencucian uang. Tahapan-tahapan tindak pidana pencucian uang sebagai berikut:

1. Tahapan placament (penempatan), yaitu menempatkan harta hasil kejahatan ke dalam sistem keuangan, seperti menempatkan harta hasil korupsi ke rekening bank atas nama istri atau anaknya;

2. Tahapan layering (pelapisan), yakni menyamarkan dan menyembunyikan asal usul harta hasil kejahatan melalui transaksi keuangan dari satu bank ke bank yang lain, bahkan dari bank satu negara ke bank negara lain sampai para penegak hukum tidak dapat mendeteksi harta hasil kejahatan tersebut;

3. Tahapan integration (penyatuan), yakni menghimpun kembali harta hasil kejahatan yang disamarkan atau disembunyikan melalui tahapan placement (penempatan) dan layering (pelapisan) ke sistem keuangan yang sah atau legal, seperti dijadikan modal perusahaan-perusahaan yang legal dan hasilnya seolah-olah telah menjadi harta yang sah.

Tiga tahapan tersebut telah diadopsi oleh Undang-Undang Nomor 8 Tahun 2010 dalam Pasal 3 untuk placement (penempatan), Pasal 4 untuk layering (pelapisan), dan Pasal 5 untuk integration (penyatuan). Jika dianalisa dengan tipologi tahapan tersebut maka tindak pidana pencucian uang yang dilakukan oleh terdakwa adalah tahapan placement (penempatan), 
terdakwa sebagai pelaku aktif, artinya terdakwa melakukan tindak pidana asal, yakni tindak pidana penyelundupan pupuk atau tindak pidana di bidang kelautan dan perikanan.

Harta kekayaan yang dihasilkan dari salah satutindak pidana asal tersebut terdakwa tempatkan atau menitipkan atau perbuatan lain melalui teman terdakwa di Flores/Maumere. Perlu diperhatikan perbuatan yang menjadi unsur pada Pasal 3 tidak hanya mentransfer tapi juga menempatkan atau menitipkan bahkan perbuatan-perbuatan lain yang tujuannya ingin menyembunyikan atau menyamarkan. Jadi menurut penulis terdakwa lebih memenuhi unsur-unsur Pasal 3.

Sementara perbuatan yang dilakukan oleh rekan terdakwa dan saksi AR merupakan tahapan layering (pelapisan) sebagaimana diatur dalam Pasal 4, perbuatan yang dilakukan rekan terdakwa ingin menyembunyikan atau menyamarkan asal usul kepemilikan harta tersebut dari pemilik aslinya. Jika penegak hukum sungguh-sungguh mau menegakkan hukum, maka rekan terdakwa dan saksi AR dapat dimintai pertanggungjawaban pidana terhadap dugaan tindak pidana pencucian uang yang dilakukannya. Jadi rekan terdakwa dan saksi AR dapat diancam dengan Pasal 4. Namun demikian harus dibuktikan unsur "diketahui atau patut menduganya" bahwa harta yang ditransfer oleh rekan terdakwa kepada saksi AR berasal dari tindak pidana penyelundupan atau tindak pidana di bidang perikanan dan kelautan.

Selain dua permasalahan di atas, permasalahan utama yang harus dianalisis penulis, yakni apakah pembuktian unsur "diketahuinya atau patut diduganya merupakan hasil tindak pidana sebagaimana dimaksud dalam Pasal 2 ayat (1)" dapat dibuktikan jikalau tindak pidana asalnya tidak dibuktikan terlebih dahulu.
Hakim dalam membuktikan Pasal 4 khususnya unsur "diketahuinya atau patut diduganya merupakan hasil tindak pidana sebagaimana dimaksud dalam Pasal 2 ayat (1)" dalam Putusan Nomor 57/PID.SUS/2014/ PN.SLR menyatakan telah terbukti meskipun tindak pidana asalnya tidak dibuktikan terlebih dahulu, hakim meyakinkan bahwa unsur tersebut telah terbukti hanya berdasarkan pernyataan terdakwa dalam BAP, bahwa terdakwa diduga pernah melakukan perjalanan ke Batam dan dilanjutkan ke Malaysia, dari kegiatan tersebut terdakwa diduga menyelundupkan pupuk cap Matahari dari Malaysia ke Indonesia. Harta kekayaan hasil dari tindak pidana tersebut yang dicuci oleh terdakwa.

Menurut Garnasih rumusan pada delik tindak pidana pencucian uang yakni Pasal 3, Pasal 4, dan Pasal 5 menimbulkan karakteristik yang berbeda dengan tindak pidana yang lain, bahwa tindak pidana pencucian uang merupakan follow up crime, sedangkan hasil kejahatan yang diproses pencucian uang disebut sebagai core crimes atau predicate offence atau disebut sebagai unlawful activity. Jika dilihat dari kronologi perbuatan maka tidak mungkin terjadi tindak pidana pencucian uang tanpa terjadi predicate offence (no money laundering without core crime) terlebih dahulu (Garnasih, 2013: 6).

Tindak pidana asal (predicate offence) di dalam Undang-Undang Nomor 8 Tahun 2010 disebutkan secara limitatif dalam Pasal 2 yaitu terdiri dari 26 jenis tindak pidana dan ditambah "semua tindak pidana yang ancaman pidananya empat tahun ke atas. Predicate offence (tindak pidana asal) menurut Arief adalah "delik-delik yang menjadi sumber dari uang haram (dirty money) atau hasil kejahatan (criminal proceeds) yang kemudian dicuci.” Beberapa negara ASEAN 
dalam merumuskan tindak pidana pencucian uang juga merumuskan tindak pidana asal (predicate offence) (Arief, 2013: 127-145), arti umumnya di negara-negara ASEAN mengakui bahwa tindak pidana pencucian uang selalu didahului oleh tindak pidana asalnya.

Garnasih melanjutkan pendapatnya di atas, perlu dipahami bahwa tindak pidana pencucian uang merupakan kejahatan lanjutan (follow up crime) yang terjadinya sangat tergantung pada adanya tindak pidana asal, meskipun antara keduanya masing-masing dikualifikasikan sebagai tindak pidana yang berdiri-sendiri, oleh karena itu, dalam memeriksa tindak pidana tersebut sebaiknya bersamaan (antara tindak pidana asal dengan tindak pidana pencucian uang) dan dibuat dalam satu bentuk dakwaan dengan bentuk surat dakwaan kumulatif. Pemahaman ini akan berimplikasi langsung pada pembuktian yaitu bahwa masing-masing tindak pidana baik tindak pidana asal maupun tindak pidana pencucian uang harus dibuktikan sebagai konsekuensi dari bentuk dakwaan kumulatif (Garnasih, 2013: 6).

Bentuk surat dakwaan kumulatif terhadap tindak pidana asal dan tindak pidana pencucian uang dapat mempermudah hakim dalam membuktikan unsur "harta kekayaan yang diketahui atau patut diduganya berasal dari tindak pidana sebagaimana dimaksud dalam Pasal 2 ayat (1) Undang-Undang Nomor 8 Tahun 2010.”

Hakim terlebih dahulu membuktikan unsur-unsur tindak pidana asal dan kemudian dengan mudah membuktikan bahwa harta kekayaan hasil dari tindak pidana asal benarbenar dia cuci melalui perbuatan sebagaimana diatur dalam Pasal 3 maupun Pasal 4, di samping itu pelaku telah dianggap mengetahui atau patut menduganya bahwa harta kekayaan yang dicuci telah berasal dari tindak pidana asal pada dakwaan kumulatif pertama tersebut.

Hakim sangat kesulitan untuk membuktikan unsur "harta kekayaan yang diketahui atau patut diduganya berasal dari tindak pidana sebagaimana dimaksud dalam Pasal 2 ayat (1) Undang-Undang Nomor 8 Tahun 2010," jika tindak pidana asalnya tidak didakwa dan tidak dibuktikan terlebih dahulu. Kecuali pada tindak pidana illicit enrichment yakni suatu instrumen hukum yang mngkriminalisasi pejabat publik yang memiliki kekayaan dan/atau peningkatan kekayaan dalam jumlah tidak wajar (tidak sesuai dengan sumber pemasukannya) tanpa mampu membuktikan bahwa aset tersebut diperoleh secara legal/sah (bukan dari tindak pidana) (Yusuf, 2013: 85).

Menurut Atmasasmita tindak pidana sebagaimana disebut sebagai illicit enrichment belum diatur di Indonesia. Dengan demikian Pasal 69 Undang-Undang Nomor 8 Tahun 2010 tidak dapat diterapkan, penyidik penuntut umum dan hakim tidak dapat melakukan penyidikan, penuntutan, dan pemeriksaan di pengadilan terhadap tindak pidana pencucian uang tanpa dibuktikan tindak pidana asalnya terlebih dahulu karena tindak pidana asal yang tidak dibuktikan terlebih dahulu adalah tindak pidana illicit enrichment dan di Indonesia belum dinyatakan sebagai tindak pidana. Dengan demikian membuktikan unsur "harta kekayaan yang diketahui atau patut diduganya berasal dari tindak pidana sebagaimana dimaksud dalam Pasal 2 ayat (1) Undang-Undang Nomor 8 Tahun 2010" terhadap terdakwa $\mathrm{R}$ tidak dapat dibuktikan kecuali tindak pidana asalnya didakwakan bersamaan dengan tindak pidana pencucian uang dan dibuktikan oleh hakim. 
Sapardjaja sebagai hakim agung menyatakan kesulitan dalam membuktikan unsur tindak pidana pencucian uang khususnya unsur "harta kekayaan yang diketahui atau patut diduganya berasal dari tindak pidana sebagaimana dimaksud dalam Pasal 2 ayat (1) Undang-Undang Nomor 8 Tahun 2010" jika tidak didakwa bersamaan dengan tindak pidana asalnya (dakwaan kumulatif).

Jika penuntut umum mendakwa secara bersamaan antara tindak pidana asal dengan tindak pidana pencucian uang hakim dengan mudah memperoleh keyakinan untuk memutus terdakwa bersalah, karena selain unsur tindak pidana pencucian uang terbukti, juga tindak pidana asalnya sangat jelas. Dengan alat bukti dan barang bukti yang cukup yang diajukan oleh penuntut umum, masalah beban pembuktian terbalik hampir tidak diperlukan lagi. Pembuktian tindak pidana pencucian uang sangatlah sulit jika dihubungkan dengan illicit enrichment, penuntut umum hanya mendakwa tindak pidana pencucian uang tanpa tindak pidana asalnya. Hakim sangat sulit membuktikan tindak pidana pencucian uang meskipun diberi wewenang untuk menerapkan pembalikan beban pembuktian.

Sapardjaja (2013: 7) melanjutkan pendapatnya dengan menegaskan bahwa pembalikan beban pembuktian yang digunakan jikalau tindak pidana pencucian uang tidak didakwa bersamaan dengan tindak pidana asalnya merupakan masalah yang sangat pelik yang harus mendapat kajian akademik. Demikian juga menurut Atmasasmita, dalam memahami tindak pidana pencucian uang perumus Undang-Undang Nomor 8 Tahun 2010 telah menyamakan tindak pidana pencucian uang dengan tindak pidana penadahan Pasal 480 KUHP. Padahal tindak pidana pencucian uang merupakan derivatif dari tindak pidana asal (predicate offence) yang secara limitatif telah dicantumkan dalam Pasal 2 ayat (1) Undang-Undang Nomor 8 Tahun 2010.

Tindak pidana penadahan merupakan tindak pidana yang berdiri dan merupakan tindak pidana selesai (voltooid delicten). Namun dalam tindak pidana penadahan, unsur "memperoleh dan seterusnya" harus dilakukan dengan sengaja sedangkan pelaku sendiri tidak perlu mengetahui asal usul benda tersebut diperoleh dari tindak pidana asal. Dengan demikian, secara teoritik hukum pidana, tindak pidana asal dalam tindak pidana pencucian uang harus dibuktikan. Namun dalam Undang-Undang Nomor 8 Tahun 2010 pembentuk undang-undang telah meniadakan kewajiban membuktikan tindak pidana asal sebagaimana diatur dalam Pasal 69.

Berdasarkan beberapa pendapat dari ahli hukum pidana dapat disimpulkan bahwa tindak pidana pencucian uang memiliki hubungan yang sangat erat dengan tindak pidana asal, bahkan tidak akan terjadi tindak pidana pencucian uang jikalau tidak didahului oleh tindak pidana asal. Di samping itu pembuktian tindak pidana pencucian uang tanpa dibuktikan terlebih dahulu sangatlah kesulitan meskipun hakim diberi kewenangan untuk menerapkan pembalikan beban pembuktian kecuali terhadap tindak pidana illicit enrichment, namun sangat disayangkan karena tindak pidana tersebut belum diatur di Indonesia.

Dengan demikian pembuktian terhadap tindak pidana pencucian uang baik pada Pasal 3 maupun Pasal 4 yang dilakukan terdakwa R dalam Putusan Nomor 57/PID.SUS/2014/PN.SLR tidak terbukti karena unsur "harta kekayaan yang diketahui atau patut diduganya berasal dari tindak pidana sebagaimana dimaksud dalam Pasal 2 ayat (1) Undang-Undang Nomor 8 Tahun 2010" 
tidak terbukti. Kenapa demikian, karena penuntut umum tidak mendakwakan pasal tindak pidana asal dari tindak pidana pencucian uang yang dilakukan terdakwa sehingga hakim tidak bisa membuktikan bahwa harta kekayaan yang dicuci melalui transfer yang dilakukan teman terdakwa kepada rekening saksi AR tidak dibuktikan bahwa hasil dari tindak pidana penyelundupan pupuk cap Matahari dari Malaysia ke Indonesia atau tindak pidana di bidang kelautan dan perikanan.

\section{KESIMPULAN}

Berdasarkan ulasan dalam pembahasan di atas dapat dirumuskan beberapa kesimpulan sebagai berikut:

1. Bahwa penyusunan surat dakwaan pada tindak pidana pencucian uang penting untuk ditentukan pasal yang didakwakan, baik pasal tindak pidana pencucian uang bersamaan dengan pasal tindak pidana asal maupun hanya pasal tindak pidana saja. Karena hal tersebut berdampak pada bentuk pembuktian pembuktian yang dilakukan oleh hakim terhadap unsur tindak pidana pencucian uang.

2. Bahwa pembuktian unsur tindak pidana pencucian uang, khususnya unsur "harta kekayaan yang diketahui atau patut diduganya berasal dari tindak pidana sebagaimana dimaksud dalam Pasal 2 ayat (1) Undang-Undang Nomor 8 Tahun 2010" tidak dapat dibuktikan jikalau tindak pidana asalnya tidak dibuktikan terlebih dahulu, tindak pidana asal tidak akan dibuktikan oleh hakim jikalau tindak pidana asalnya tidak didakwakan secara bersamaan dengan tindak pidana pencucian uang.

\section{SARAN}

Berdasarkan uraian dalam pembahasan dan kesimpulan di atas dapat dirumuskan saran-saran sebagai berikut:

1. Hakim dalam membuktikan perkara tindak pidana pencucian uang harus menyesuaikan dengan surat dakwaan yang disusun oleh penuntut umum.

2. Sedangkan hakim dalam membuktikan tindak pidana pencucian uang hendaknya membuktikan terlebih dahulu tindak pidana asalnya, sehingga harta kekayaan yang menjadi objek pencucian uang benarbenar berasal dari tindak pidana asal sebagaimana diatur dalam Pasal 2 ayat (1) Undang-Undang Nomor 8 Tahun 2010.

\section{DAFTAR ACUAN}

Arief, B.N. (2013). Kapita selekta hukum pidana. Bandung: Citra Aditya Bakti.

Atmasasmita, R. (2010). Globalisasi \& kejahatan bisnis. Jakarta: Kencana Prenada Media Group. (2013, September 10). Analisis hukum UU RI Nomor 8 Tahun 2010 tentang Pencegahan \& Pemberantasan Tindak Pidana Pencucian Uang. Makalah Seminar Nasional tentang Kajian Tindak Pidana Pencucian Uang dari Teori Hukum Pidana \& Praktik. Surakarta.

Darwin, P. (2012). Money laundering. Tanpa kota penerbit: Sinar Ilmu.

Garnasih, Y. (2013, September 10). Tindak pidana pencucian uang dalam teori \& praktik. Makalah Seminar Nasional tentang Kajian Tindak Pidana Pencucian Uang dari Teori Hukum Pidana \& 
Praktik. Surakarta.

Hamzah, A. (2010). Hukum acara pidana Indonesia. Jakarta: Sinar Grafika.

Harahap, Y. (2010). Pembahasan permasalahan \& penerapan KUHP. Jakarta: Sinar Grafika.

Harmadi. (2011). Kejahatan pencucian uang. Malang: Setara Press.

Hiariej, E.O.S. (2014). Prinsip-prinsip hukum pidana. Yogyakarta: Cahaya Atma Pustaka.

Husein, Y. (2011, Februari 18). Peran PPATK Dalam Mencegah \& Memberantas Tindak Pidana Pencucian Uang Berdasarkan UU No. 8 Tahun 2010. Makalah. disampaikan di Fakultas Hukum Universitas Jember.

Ibrahim, J. (2006). Teori \& metodologi penelitian hukum normatif. Malang: Bayumidia.

Marzuki, P.M. (2016). Penelitian hukum. Jakarta: Prenadamedia Group.

Moeljatno. (2009). Asas-asas hukum pidana. Jakarta: Rineka Cipta.

Muhammad, R. (2007). Hukum acara pidana kontemporer. Bandung: Citra Aditya Bakti.

Sapardjaja, K.E. (2013, September 10). Beban pembuktian terbalik dalam praktik. Makalah Seminar Nasional tentang Kajian Tindak Pidana Pencucian Uang dari Teori Hukum Pidana \& Praktik. Surakarta.

Sjahdeini, S.R. (2007). Seluk-beluk tindak pidana pencucian uang \& pembiayaan terorisme. Jakarta: Pustaka Utama Grafiti.

Soekanto, S. (2010). Pengantar penelitian hukum. Jakarta: Universitas Indonesia Press.

Uly, J. \& Tanya, B.L. (2009). Money laundering. Surabaya: Laros.
Utomo, P. (2013). Memahami asset recovery \& gatekeeper. Jakarta: Indonesia Legal Roundtable.

Yusuf, M. (2013). Merampas aset korupsi. Jakarta: Penerbit Buku Kompas. 